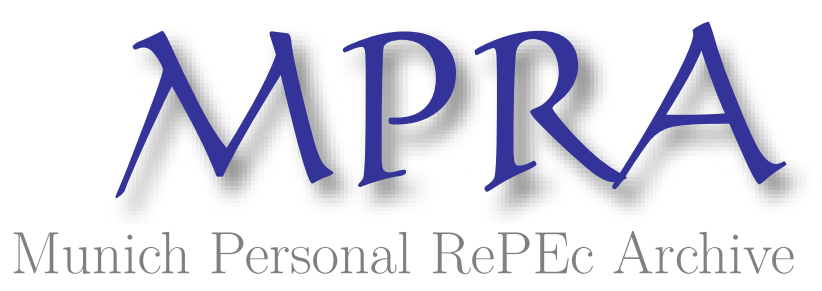

\title{
Evaluating the effectiveness of the procurement Acts in public financial administration; the case study in Ghana
}

Tweneboah Senzu, Emmanuel and Ndebugri, Haruna

Cape Coast Technical University, Bastiat Institute Ghana

2 January 2017

Online at https://mpra.ub.uni-muenchen.de/79068/

MPRA Paper No. 79068, posted 11 May 2017 05:33 UTC 


\title{
Evaluating the Effectiveness of the Procurement Acts in Public Financial Administration; the Case Study in Ghana
}

\author{
Cape Coast Technical University
}

Bastiat Institute Ghana

\author{
Emmanuel Tweneboah Senzu \\ (Tsenzu@pc.edu.gh) \\ $\&$ \\ Haruna Ndebugri \\ (Handeburi@gmail.com)
}




\subsection{ABSTRACT}

This paper dissects into the deepest fiber of Ghana Procurement Acts, empirically examine it effectiveness and economic impact on Public Financial Administration and define the required improvement

Key words: Public Financial Administration, Economic management, Procurement Acts, Procurement System, Development Economics

\subsection{INTRODUCTION}

Effective financial management and procurement systems have being one of the developmental challenges facing most developing countries in Sub-Saharan Africa, and Ghana is no exception. According to Sarfo and Baah-Mintah (2013) financial management, especially public financial management is an attempt made by government to ensure that consistently, the budget is either in balanced or a surplus type. These are largely achieved through ensuring adequate receipts from taxes and non-tax sources, and reducing public expenditure levels. In Ghana, public procurement is a major activity of government that generates important financial resources and has been viewed as part of a wider reform agenda targeted at improving public financial management (Republic of Ghana, 2001). The primary concept of procurement is based on the premise that advanced planning, scheduling, and group buying would result in cost savings, more efficient organizational operation, and therefore improve transparency and accountability.

A procurement system's main objective is to manage this process, providing turnaround time for invoices, tracking of total spending by commodity type, as well as financial commitments and cash flow management. The complete implementation of a procurement system usually results in significant changes to the existing business process, as the system would require certain internal controls and procedures to be in place.

The procurement Act of Ghana, Act 663 (2003), was enacted and promulgated by parliament of the republic of Ghana to, among other things; bring sanity and conformity to public procurement by instituting bodies and principles that harmonizes the public procurement process and activities. The objective of the law is to ensure cost effectiveness, efficiency, promote fairness, 
transparency and ensure that public procurement is non-discriminatory (Foster, 2014). Procurement as an integral part of any fiscal policy or programme directed toward achieving effective and efficient public financial management and national development (Chowdhury \& Kirkpatrick, 1994). Adjei (2006) reveals that public procurement between 1982 and 2002 represented about $24 \%$ of total imports of Ghana and apart from personnel emoluments, public procurements currently takes between $50 \%-70 \%$ of the national budget. Public Procurement continues to accounts for a significant portion of Gross Domestic Product (GDP). Therefore an improvement in the public procurement process will in no doubt ensure value for money in government expenditure, which is essential to a country facing enormous developmental challenges. According to Sarfo and Baah-Mintah (2013) procurement as an economic instrument for guaranteeing national development, when well planned and implemented, as the potency of contributing to the realization of the following; improves resource mobilization, promote debt sustainability and effective management of debt, improves public expenditure management, enhances national income generation and reduce economic and financial dependency.

The Act has, since its inception, introduced several relevant modern procurement principles that are expected to correct the rot and anomalies that were widely associated with public procurement. This notwithstanding, the implementation of Act 663 has been quite challenging. The reactions to Act 663 by key stakeholders since its enactment about a decade ago have been both positive and negative. Some view it as a universal remedy to the numerous problems that bedevil public procurement in Ghana. On the other hand, others see it as an instrument that over rely on competition and are therefore inadequate and lack the needed strength to curb the various moral concerns that characterize public procurement practice. The aim of this study is to investigate the efficiency and the economic impact of the Public Procurement Act after exactly a decade of its enforcement on public procurement systems in order to establish an empirical argument to support the extent, to which the objectives of the law have been achieved.

\subsection{Problem Construct}

The Government of Ghana has since 1961 in its quest to ensure sanity in the public expenditure process launched the Public Financial Management Reform Programme (PUFMARP). The purpose of the programme was to improve financial management in Ghana. Key among the 
findings of the PUFMARP was the weaknesses in the procurement system. Some of the major weaknesses included were;

i. Lack of comprehensive public procurement policy

ii. Lack of central body with technical expertise

iii. Absence of clearly defined roles and responsibilities for procurement entities

iv. Absence of comprehensive legal regime to safeguard public procurement

v. Lack of rules and regulations to guide, direct, train and monitor public procurement (Ameyaw, Mensah \& Osei-Tutu, 2012).

This led to the establishment of the Public Procurement Oversight Group in 1999. The aim of this group was to steer the design of a comprehensive public procurement reform programme which led to the drafting of a public procurement bill in September 2002 that was passed into law on 31 December 2003. Since the enactment of the procurement Act 663, many studies (Foster, 2014; Sarfo \& Baah-Mintah, 2013; Ameyaw, Mensah \& Osei-Tutu, 2012; Adjei, 2006) have acknowledged its ability to ensure judicious and efficient use of state resources, a transparent and non-discriminatory public procurement system and to reduce or eliminate corruption in the procurement process. However, the implementation of this well intentioned act has being met with several challenges that ails the health of its objective (Dabaga, 2013). According to Dabaga (2013) the lack of clear procedures for emergency procurement, slow pace in regularizing the draft regulations, lack of qualified procurement personnel and high cost of advertisement. Though the public procurement act has established guidelines, principles and tender committees to take charge of its object, it has, however, failed to clearly provide for emergency procurement procedures. This has culminated in procurement officers resorting to their own discretion during emergency procurement which is subject to immense human error (Dabaga, 2013). This is evident in the gargantuan judgment debts paid by the government of Ghana to individuals and corporate bodies. This palpable weakness of the public procurement Act remains one of the major ports of heckling, abuse, foul play and transgression in the business of public procurement right from the Board to subcommittee levels (Public Procurement Authority, 2006). In an attempt to promote transparency and accountability in the dealings of the Public Procurement Authority, the Act has directed that, notices be given in a widely circulated local and international newspaper. However, this endeavor has over the years increased the cost 
of procuring materials, logistics and services for public entities, some of which, the cost of advertisement out-weighs the real cost of the items. This study therefore takes a critical look at how the procurement law has affected procurement systems in Public Sector Administration.

\subsection{OBJECTIVE AND SIGNFICANCE OF STUDY}

The main objective of the study is to evaluate the effectiveness and economic impact of the procurement law on procurement systems in Public Sector Administration. Specific objectives for the study are stated below:

1. Ascertain whether all public sector organizations; procurement policies and practices are in compliance with the Public Procurement Act, act 663 (2003).

2. Examine whether there is transparency, accountability and responsibility in the procurement systems.

3. Determine how procurement of works, goods and services can be improved in public sector organizations

The study seeks to provide an insight into the procurement systems in Public Sector Administration in Ghana. This study seeks to contribute to knowledge and development of literature in the subject area, which is under investigation and serve also as a basis for further research to strengthen the knowledge base in this faculty. The findings will serve as a valuable reference to educationists and policy makers in trying to address some of the challenges of the procurement Act. It also seeks to provide a framework for ensuring effective procurement practices in both Public and private sector enterprises, so as to enhance good corporate governance through transparency and accountability. It also seeks to influence national and corporate procurement policies which would be of relevance to other public institutions and would also serve as a guide on what strategies to adopt in efficient procurement practices. 


\subsection{THEORY AND LITERATURE REVIEW}

Public procurement is the process by which governments and other publicly-funded entities acquire goods, works, and services needed to implement public projects. It accounts for at least $15 \%$ of the world's gross domestic product (GDP), and even more in African countries (World Bank, 2013). Governments over the past few decades having looked at ways to get down public expenditure and ensure efficient and effective use of the taxpayers resources. To this end, public procurement is needed. Public procurement is the acquisition of goods and services at the best possible total cost by the government and public institutions. According to Sarfo (2011), public procurement is a practice that is used by public sector organizations to acquire goods, services and works from third parties meaning suppliers. It includes money spent by the public sector to provide key services directly to citizens. The only way it can be beneficial to all would be for it to be effective. It is said that "the public sector in the UK spends over $£ 150$ billion a year on goods and services necessary to deliver public services" (European Commission, 2007).It is estimated that in Ghana, public procurement accounts form 70 to 80 per cent of the total government expenditure (Kumak, 2012).

By reducing bottlenecks, combating corruption, and building capacity in procurement, helps governments maximize the buying power of their budgets and improve the quality of service delivery to their citizens. Competitive and transparent public procurement systems are therefore a key element to achieving sustainable development and more prosperous societies. For the above reasons and more, government of Ghana has over the years underscored the needs for efficient and transparent procurement procedures that has the capacity of assisting local suppliers and improve their competencies in applying for public contracts. However, this is the area bedeviled with corrupt practices. Because public funds are used to procure goods, works and services, it becomes a big drain on the nation's coffers if public officers misappropriate the funds meant for development.

In view of this, the Government of Ghana introduced the Public Procurement Act in 2003 to bring sanity into public procurement and ensure that the nation saved money by cutting out dubious practices. The principal objective of any transparent and efficient public procurement 
was the attainment of a timely and cost effective implementation of public sector activities devoid of all traces of corruption (Ghanaweb, 2007). This paper therefore assembles relevant literature in connection with the procurement act to provide a theoretical foundation for the study. Issues discussed include the brief history of the public procurement law in Ghana, the objectives and scope of act 663 in procurements, challenges of the procurement act 663, the EU public procurement rules in compared with procurement act (663) in Ghana, corruption associated with public procurement.

The European Union (2013) defines procurement as the act of obtaining or buying goods and services. The process includes preparation and processing of a demand as well as the end receipt and approval of payment. Cole (2007) defines procurement as the purchase of merchandise or services at the optimum possible total cost in the correct amount and quality. He further reiterated that Procurement can also be simply defined as the procedure in which goods or commodities are bought when prices are low. The process of procurement often involves; purchase planning, standards determination, specifications development, supplier research and selection, value analysis, financing, price negotiation, making the purchase, supply contract administration, inventory control and stores, disposals and other related functions. Rose-Ackerman (1999) cited by Søreide (2002) divides procurement into three categories:

(i) Purchases that require specialized research and development, such as newly designed military aircraft.

(ii) Purchases of complex, special purpose projects, such as dams or port facilities that do not involve advances in technology but require managerial and organizational skills.

(iii) Purchases of standard products sold in open markets, such as motor vehicles or medical supplies (off-the shelf purchase). Customized versions of products otherwise available in open markets, such as special purpose computer systems or fleets of police cars. 
However, according to the Business Dictionary (2011), "Procurement" is the overarching function that describes the activities and processes through which an organization acquire goods and services. Procurement is the business management function that ensures identification, sourcing, access and management of the external resources that an organization needs or may need to fulfill its strategic objectives (CIPS, 2013).Procurement is the business management function that ensures identification, sourcing, access and management of the external resources that an organization needs or may need to fulfill its strategic objectives.

Procurement exists to explore supply market opportunities and to implement resourcing strategies that deliver the best possible supply outcome to the organization, its stakeholders and customers. Procurement applies the science and art of external resource and supply management through a body of knowledge interpreted by competent practitioners and professionals (CIPS, 2013).

The process of procurement is often part of an organization's operational strategy as the ability of an organization to purchase certain key resources at the right time and prize, would determine their survival or otherwise in today's competitive business environment their success of performance is lean. According to Miles (2015) "Procurement is a complex process that can help organizations become more efficient". This is because all their goods and services would be bought at the right quality, quantity, price and they will be delivered 'just in time', thereby reducing the need to stockpile goods and parts. Reducing the amount of goods that are stored will reduces the amount of resources used to store them. It also ensures that they are not overly transported, which means there is less risk of them being damaged and no resources are required to transport them. By buying goods that are of the right quality means that they are not too good for the role that they intended to fulfill, as such would be at the right price. But they will also not be sub-standard, so there is less chance of the parts and goods causing defects. One crucial role procurement plays for organizations, is its ability to create relationships. Creating good relationships with suppliers also mean that they will be flexible and help out if a sudden increase in volume of goods is required. So procurement really is vital and can really transform companies when it is done right. Although, procurement may not actually produce the goods that are sold, it can actually help to increase profits due to its ability to ensure that operational demands are met (Miles, 2015). 
However, it is important to note that procurement is and distinct from purchasing. The term purchasing refers to the process of ordering and receiving goods and services. It is a subset of the wider procurement process. Generally, purchasing refers to the process involved in ordering goods such as request, approval, and creation of a purchase order record and the receipting of goods (CIPS, 2013). Whiles procurement involves the activities involved in establishing fundamental requirements, sourcing activities such as market research, vendor evaluation and negotiation of contracts play a crucial role in successful procurement system. It can also include the purchasing activities required to order and receive goods. Corporations and public bodies often define procurement as the processes intended to promote fair and open competition for their business while minimizing exposure to fraud and collusion (Wikipedia, 2011). This according to Cole (2007) is made smoother by promoting a good business relationship between the buyer and the supplier.

According to Ohene- Addae (2012) the process of procurement may differ from company to company, and a government institution may have a slightly different procurement process compared to a private company. The procurement procedure may differ according to the product and the uses of the product. Another important factor that is usually included in the definitions of procurement is the amount in which the product is bought. This is important because the amounts of goods bought are inversely proportional to their cost. Thus, procurement is a process that is carried out by almost every company and individual for its own personal gain or for profits, which involves buying of commodities by choosing the appropriate bidder.

According CIPS (2014) procurement cycle refers to a cyclical process of key steps when procuring goods or services. Ohene- Addae (2012) refers to it as a roadmap of activities within the procurement function. The project procurement cycle reflects the procurement activities from the decision to purchase the material or service through to the payment of bills and closing of procurement contracts. It starts from the identification of a need and conducting market analysis through to the process of selecting the supplier, managing their performance and reviewing lessons learnt. It establishes key activities required at every stage of the procurement process while at the same time providing a benchmark for the monitoring and evaluation of the process by procurement monitors and evaluators (Ohene-Addae, 2012). 
In most studies conducted on public procurement, the procurement process is considered to include contract administration (Handfield, 2011). Other studies such as Lynch (2012) and Cole (2007) believes that the public procurement process ends with contract award and that anything after contract award is considered contract administration. However, for the purpose of this, the procurement cycle would encompass activities occurring within the entire supply chain with it procurement system as shown in Figure A below. This is because, though the procurement Act (Act 663) did not stress on the storage and distribution functions of the supply chain, its emphasis on the disposal of stores, plant and equipment makes it imperative to include all activities of the supply chain. According to the procurement Act (Act 663); the procurement cycle consist of activities such as planning, sourcing, contracting, contract management, storing, distribution, disposal and evaluation.

Fig A. Procurement Cycle

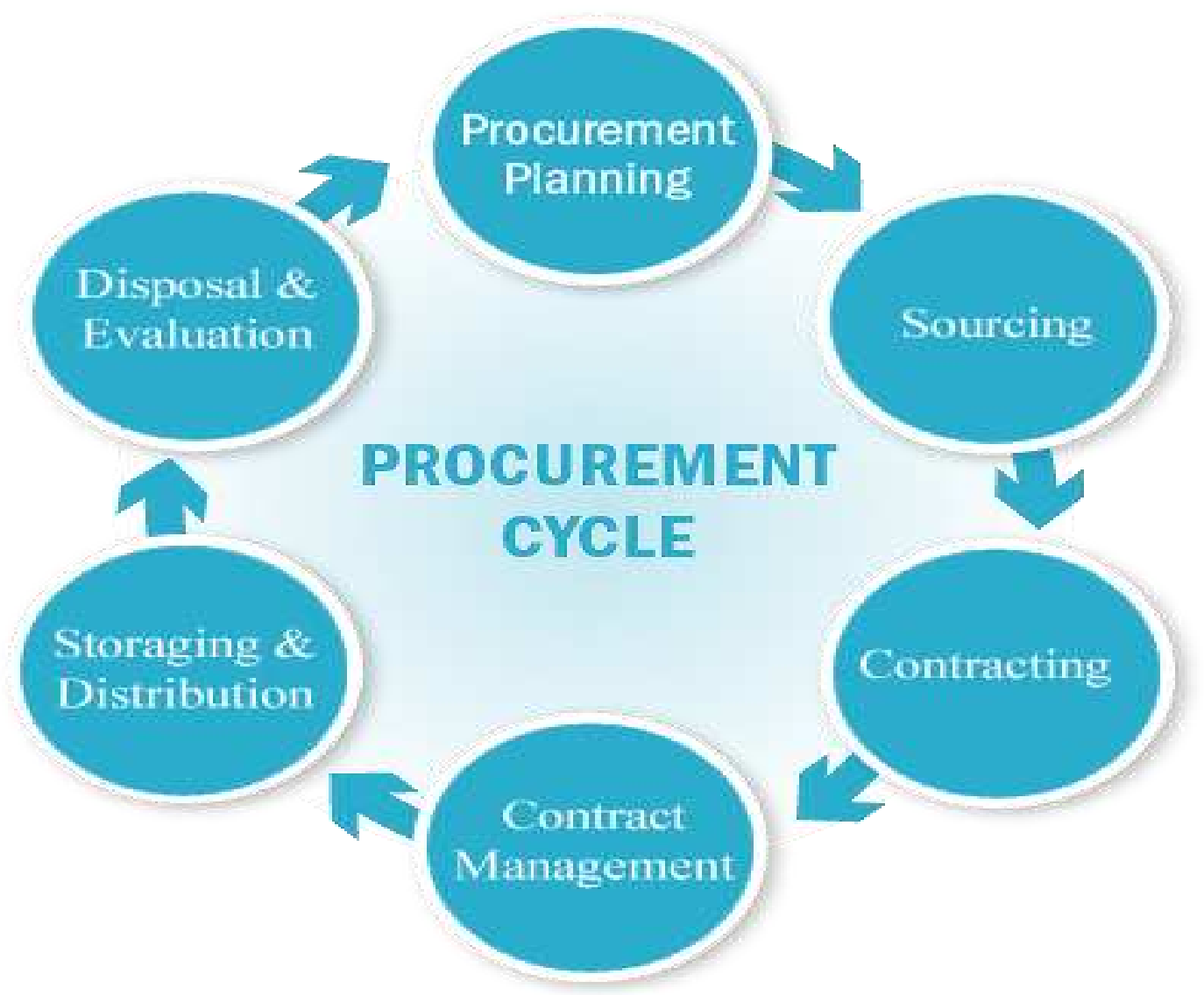

$P$ a g e $10 \mid 41$ 


\subsection{Procurement Planning}

Procurement planning is the process whereby an organization decides what to buy, when and from what source (Lynch, 2012). Himmie (2010) describes it as a process whereby procurement practitioners sketch out in advance an arrangement in a diagram on a plan as to what, which , when and how purchases are to be conducted in a given period. During the procurement planning process the procurement method is assigned and the expectations for fulfillment of procurement requirements determined. Lynch (2012) and Himmie (2010) opinioned that effective Procurement Planning is essential for all procuring entities in the implementation of the purchasing objectives for the following reasons:

1. An effective plan saves time and money. This is because planners can estimate the time required completing the procurement process and award contract for each requirement.

2. An effective plan serves as a conduit to achieving entity's objectives. This permits the creation of a procurement strategy for procuring each requirement that will be included in the procurement plan. Such strategy includes a market survey and determining the applicable procurement method given the requirement and the circumstances.

3. An effective plan allows planners to determine if expectations are realistic; particularly the expectations of the requesting entities, which usually expect their requirements met on short notice and over a shorter period than the application of the corresponding procurement method allows

4. An effective plan ensures compliance with regulatory policies.

5. An effective plan provides a framework to guide procurement officers in the achievement of their tasks and duties.

\subsection{Sourcing}

Sourcing is simply the process whereby an organization finds suppliers of goods and services. It's an approach to procurement whereby the business needs of the organization are matched with the supplier market (Wallace \& Xia, 2014). It is much more than simply centralizing procurement. The approach is founded on a detailed understanding of both the spend profile of the organization as well as of the supplier market. This understanding is continually updated in 
order to deliver ongoing improvements to the organizations sourcing and procurement performance.

Activities within this phase include pre-qualification of potential suppliers, preparation and issue of tender documents, requests for quotations or for proposals; evaluation of responses and the selection of the successful tenderer (Ohene-Addae, 2012). According to Basu (1995) strategic sourcing skills play an important role in the cost structure and competitiveness of both small and large businesses. These skills involve analyzing high-volume purchases and developing longterm partnerships with a select group of suppliers that are capable of providing quality products and services at low costs. High-volume purchases are the best candidates for strategic sourcing because they are likely to have the greatest impact on lowering cost structures.

\subsection{Contracting and contract management}

After suppliers of goods and services have been selected, there is the need for a written legallybinding agreement between the parties identifying rights and obligations of both parties. This phase is crucial because its includes the negotiation of the terms and conditions in contracts and ensuring compliance with the terms and conditions, as well as documenting and agreeing on any changes or amendments that may arise during its implementation or execution. According to IACCM (2011) it can be summarized as the process of systematically and efficiently managing contract creation, execution, and analysis for the purpose of maximizing financial, operational performance and minimizing risk.

\subsection{Storage, Distribution and Disposal}

Storage comes in when goods procured are not being used immediately and therefore the need to store them to ensure that no damage or loss occurs. The timely availability of goods can be very crucial to an organization's operation. Goods may require specialized storage facilities or may have very limited shelf life so the effective storage, handling and management of stock levels are 
important. Goods in storage need to be delivered to their final destination for usage according the requirements of the customer or end-user. Distribution may involve complex in-country supply chains with delivery to multiple regional stores facilities or end-user sites (Ohene-Addae, 2012).

There may also be the need to respond to varying user demands and to transport goods through difficult environments and terrain with very poor infrastructure (The Public Procurement Act, Act 663,). With respect to disposal, unserviceable, obsolete or surplus stocks may have to be disposed of and depending on the nature of the goods and their condition may be sold by public tender or auction, transferred to another public organization or destroyed. It is important to make appropriate adjustments to accounts to reflect the value of the goods disposed off and any income that may have been generated during the disposal (Ohene-Addae, 2012).

\subsection{Evaluation}

The procurement evaluation involves collecting knowledge gained throughout the procurement process and using it to ascertain whether the organizational procurement needs and expectations have been fulfilled and whether "value for money" has been achieved. The procurement evaluation step is geared towards eliciting ideas for improving and optimizing the achievement of procurement needs and stakeholder satisfaction in the outcomes of procurement projects in the future. According to Alarcón, Rivas, and Serpell (1999) the evaluation stage comprises the following steps: establishing the group of people to be interviewed; value stream maps, general and detailed; project surveys; review of performance indicators; analysis of nonconformity reports; cause-effect analysis regarding delays, costs, time cycles and others. This stage is crucial in ensuring the procurement process fulfill its strategic function of improving organizational productivity and profitability. 


\subsubsection{The Brief History of Public Procurement Law in Ghana}

The period between independence and 1996, procurement was guided by many different rules. Government officials struggled to identify which rules to follow, due to lack of existing policy framework for public procurement, lack of existing institutional arrangement, and the absence of a Central Body for Procurement (Suleiman, 2010). Therefore in 1969, the Government of Ghana embarked upon an exercise to reform the Public Procurement System as an integral part of a wider Public Financial Management Reform Programme (PUFMARP).The exercise was to improve the overall public financial management in the country. The reform exercise identified shortcoming and organizational weaknesses inherent in the country's procurement system. These include the absence of a comprehensive public procurement policy and the lack of a comprehensive legal regime to safeguard the integrity of the public procurement system and finally, the absence of a central body with the requisite capability, technical expertise and competence to develop a coherent public procurement policy.

These findings led to the establishment of the Public Procurement Oversight Group (PPOG) in 1999. The aim of the group was to design and coordinate the reform and also to oversee the improvement of public financial system in Ghana. This led to the drafting of the public procurement bill in September 2002 (Ameyaw, Mensah \& Osei-Tutu, 2012). In 2003, the Government of Ghana enacted the Public Procurement Act, 2003 (Act 663) to address the inadequacies in the public financial system. This act came to replace the many different rules that guided procurement activities. The Act (Act 663) establishes the public procurement board, Tender committees and Tender Review Board; it specifies an outlined rules for the procurement methods, procedures, appeals by tenderers and disposal of stores; it further defines offences and applicable penalties and specifies thresholds in schedules to the Act; and finally, it authorizes the issue of regulations which are enforceable under the Act.

The Act is applicable to procurement, financed from public fund- wholly or partly, procurement financed with government loans, including foreign aid funds, and disposal of public stores, plants and equipment (The Public Procurement Oversight Group, 2002). The Act was to put in place appropriate administrative and institutional arrangements to oversee the procurement system. However, after 12years of the enactment of the procurement law, there still exist some challenges. The focus of this study therefore is to find out these challenges and suggest a way 
forward or improvement.

\subsubsection{The legal and institutional framework for public procurement in Ghana}

The Government launched the Public Financial Management Reform Program (PUFMARP) in 1996 with the aim of improving the overall public financial management in the country. In 1999, the Government established the Public Procurement Oversight Group to manage the development of a comprehensive public procurement reform programme. The Public Procurement Bill was drafted in 2002 and this was passed into law on 31st December 2003 as the Public Procurement Act of 2003, Act 663 (Adjei, 2006).

The PPA, 2003 (Act 663) establishes the Procurement Structures in respect of the Public Procurement Board and provides the administration and institutional arrangement for procurement in respect of Tender Committees, Tender Evaluating Panels and Tender Review Boards. Each of these structures has its designated function to ensure the smooth flow of the procurement processes. The object of the Board is to harmonize the processes of public procurement in the public service to secure a judicious, economic and efficient use of state resources in public procurement and ensure that public procurement is carried out in a fair, transparent and non-discriminatory manner(Section 2, Act 663) (The Public Procurement Oversight Group, 2002).

\subsubsection{Objectives and Scope of Act 663 in Procurements for Ghana}

The main objectives of Act 663 are to harmonize public procurement processes in the public service, is to secure judicious, economic and efficient use of state resources and to ensure that public procurement functions undertaken within the public sector are fair, transparent and nondiscriminatory. The Act makes reference to procurements financed wholly or partly from public funds; with respect of procurement of goods, works, services and contract administration. Reference is also made to disposal of public stores and equipment and procurements financed by funds or loans taken by the government of Ghana, including foreign aid funds. Act 663 however has some exceptions and does not apply to some situations such as: 
- where the Minister decides that alternative procedures are of the national interest

- Where a loan or funding agreement specifies alternative procedures and excludes stores management and/or distribution. (Source: Republic of Ghana Public Procurement Act, Act 663 cited by Ohene- Addae, 2012).

\subsubsection{Noted Challenges of the Procurement Act 663 (2003)}

The procurement Act of Ghana, Act 663 (2003), was enacted and promulgated by parliament of the republic of Ghana to promote fairness, transparency and ensure that public procurement is carried out in non-discriminatory manner. This was the spirit behind the law to bring sanity and conformity to public procurement activities by instituting bodies and principles that harmonizes the public procurement process. The Act has, since in its inception, introduced several relevant modern procurement principles that are expected to correct the rot and anomalies that were widely associated with public procurement. However, the implementation of this well intentioned act has being met with several challenges that ails the health of its object. A studies by Ameyaw, Mensah and Osei-Tutu (2012) and Dagaba (2013) identified among other things low capacity of procurement professionals, low interaction between procurement entities and the Public Procurement Authority (PPA), deliberate controlling of competition, non-compliance with provisions of the law, splitting of contracts into smaller lots, lack of clear procedures for emergency procurement, high cost of advertisement, slow pace in regularizing the draft regulations, lack of funds and non-cooperativeness of suppliers, as the major challenges militating against the implementation of the Public Procurement Law.

Studies by Dagaba (2013) asserted that though the public procurement act has established guidelines, principles and tender committees to take charge of its object, it has, however, failed to clearly provide for emergency procurement procedures. This has culminated in procurement

officers resorting to their own discretion during emergency procurement which is subject to immense human error. A study conducted by Ameyaw, Mensah and Osei-Tutu (2012) to review 205 goods contracts revealed that 33 per cent were procured via Sole Sourcing (SS), 62 per cent by Request for Quotation (RFQ) and 4 per cent by National Competitive Tendering (NCT), Further 22 per cent and 46 percent of the respondents had engaged in Sole Sourcing (SS) and 
Request for Quotation (RFQ) respectively. The reasons given for the high percent in Sole Sourcing and Request for Quotation as the preferred options for goods procurement reveal that lack of funds, lack of clear cut emergency procedures and the uncooperativeness of suppliers were behind the high inclination towards Sole Sourcing.

The public procurement authority, after its review in 2006, reported that there is lack of qualified procurement personnel in the system that cause a lot of inconsistencies leading to gross inefficiency of the concept (Dagaba, 2013). In section $3(\mathrm{k})$ of the public procurement act clearly mandates that the procurement board need to "develop, promote, and support training and professional development of persons engaged in public procurement and ensure adherence of the trained persons to ethical standards". This however, seems to be the opposite of what is exactly on the ground. A Country Procurement Assessment Report (CPAR), prepared by a team of Government officials, World Bank and donor staff, and national consultants, reveals substantial inefficiency in public procurement and concludes that the principle of "value for money" is not achieved (Ameyaw, Mensah \& Osei-Tutu, 2011). This is true for both governments financed and donor financed procurement. The main findings of the 2002 Country Portfolio Performance Review of World Bank projects also reviewed slow project implementation and disbursement among other factors due to, a large extent of inadequate procurement planning, non-transparent procurement procedures and poor contract management. Also in a review of 132 works contract which constitute an important part of public Expenditure in 2002 indicated that about 84\% incurred cost-overruns of up to $30 \%$ of the initial amount (World Bank, 2003). Similar findings

of public procurement weaknesses were recorded in the 1996 Country Procurement Assessment Report (World Bank, 1996). All of which it is highly attributed to professional incompetence of procurement officers.

\subsubsection{The EU Public Procurement Acts and Rules}

The European Union is a politico economic union of 28 member states that are located primarily in Europe. The EU was created in the aftermath of the Second World War. The first steps were to foster economic cooperation: the idea being that countries that trade with one another become economically interdependent and so more likely to avoid conflict. The result was the European 
Economic Community (EEC), created in 1958, and initially increasing economic cooperation between six countries: Belgium, Germany, France, Italy, Luxembourg and the Netherlands. Since then, a huge single market has been created and continues to develop towards its full potential (EU, 2014).

The EU operates through a system of supranational institutions and intergovernmental negotiations in decisions by the member states. The European Commission, one of the four institutions of the European Union. The European Commission's main function is to propose legislations to the European Parliament and the council of the European Union, administer and implement EU policies, enforce EU laws and negotiate international agreements. However, it also has three roles that are distinct to the public procurement law. First, the commission proposes legislation, and engages in related consultations. Secondly, it provides guidance on the law through publishing explanatory notes. Lastly, it enforces the law using its legal powers under the EC Treaty. The European Commission uses its powers to investigate and proceed against infringements in those states of the EC public procurement law. It is believed that public procurement accounts for 16.3 per cent of the EU's GDP (Arrowsmith, 2010). The EUs public procurement law is rooted in the Treaty of Rome of 1957 established by the European Economic Community (EEC) which was later named European Commission (EU) under the Maastricht Treaty of 1992.

According to Matthew (2010) cited by Gnanih (2012) and Agyekum-Kwatiah (2014) the commission's power to enforce the procurement rules is rooted in Article 226 of the EC Treaty. When a country does not apply the rules set out, the commission demands an explanation of the issue at hand. If it was not satisfied with the answer, it makes formal request to the Member State to comply with the law within a fixed period. When the commission notices that the country is not complying, with its power vested upon, take actions against a stubborn member before the ECJ for judgment on the matter. Clearly these set of rules would push the Member States of the EU to abide. The ECJ may grant permission for the pending contract to be suspended based on the merits of the project even after it has been awarded. Member states under the article 228 of the EC treaty obliged to comply with the ECJ judgment. 
The Public Procurement Act 663 (2003) also has similar provisions. Act 663 empowers the public procurement board under Section 3(q) (r) to blacklist offenders of the law. Again, Section 92 and 93 of the PPA 2003(Act 663) spells out what constitute offences and corrupt practices related to procurement and a fine of 1000 penalty units or a term of imprisonment not exceeding five years or to both upon summary conviction. However, according to Agyekum-Kwatiah (2014) the fine of 1000 penalty units enshrined in Act 663 is not biting enough to serve as a deterrent for most big time stakeholders like contractors, suppliers and consultants who might find it more lucrative to bend the rules than to follow the legal procedure required. It is therefore believed that for the procurement act to be as efficient, effective, and transparent, there is the need to ensure that the punitive measures in the law are enforced such as to deter people from contravening the law. This is because simply having a public procurement act does not solve the problems of effectiveness, accountability, efficiency and transparency, but enforcing the rules would go a long way just as the EUs public procurement rules does.

\subsubsection{Public procurement and Corruption}

The European Union (2013) defines corruption as the abuse of power for private gain. Public procurement is the acquisition of goods and services at the best possible total cost by the government and public institutions. It is estimated that public procurement accounts for 50 to 70 per cent of the total government expenditure (Adjei, 2006). Poisson (2010) asserts that public officials are always confronted with corrupt practices and such corruption within public procurement is not a new phenomenon; however research began only a decade ago. Studies by Tanzi and Davoodi (1998) and Mauro (1997) have established a link between corruption, collusion and public procurement. They were of the view that corruption affects the allocation of public spending as investment decisions are influenced by the opportunity to obtain bribes. As result large construction projects (e.g. big dams) are given priority than health and education

projects, while spending on operation and maintenance is neglected. They also opined that a result of corruption public officials show a total disregard of existing procurement laws and procedures. Politicians may also be motivated to create inefficient rules intended only to generate rents for the public officials (Tanzi \& Davoodi, 1998). 
According to European Union (2013) in public procurement, abuse of power can lead to a secret vertical relationship between one or more bidders and the procurement official, which materializes into a conflict of interest, bribery or kickback. Another dimension of abuse of power for private gain is a secret horizontal relationship between bidders, especially with the involvement of a corrupt inside official (collusion, bid rigging). Since corruption and collusion frequently occur in tandem and have ultimately the same effect, a public contract is awarded on a fraud basis other than fair competition and the merit of the successful contractor as result maximum value for public money is not achieved.

In countries where corruption is a common problem, it tends to disturb the market mechanisms and impede economic development. According to Søreide (2002) corruption in public procurement makes the officials or the politicians in charge purchase goods or services from the best briber, instead of choosing the best price-quality combination. The result had always presented highly costed construction projects and acquisition of goods not actually needed. However, it is difficult to determine a public official's involvement in corruption practices, since it is a two way exchange network where both parties (the giver and taker) benefits. This study will further attempt delve deeper in the issues of corruption in the public procurement and try to ascertain whether the enactment of the procurement act has helped improve accountability and transparency within the public procurement system.

\subsection{METHODS AND EMPIRICAL ANALYSIS}

The paper uses this section to elucidate the methodological approach to empirically present an argument that contributes to this branch of knowledge in Finance and economic management.

\subsection{Research Design}

The study is a descriptive survey method. The study is non-interventional and has the purpose of examining the impact of the procurement act, Act 633 (2003). According to Gay (1992) as cited by Amedahe (2002) the descriptive survey research design involves the collecting of data in order to test hypotheses or answer research questions concerning the current status of the subject of study as it describe, and document aspects of a situation that naturally occurs, which the 
researcher found it appropriate to give a clear picture of the impact of procurement act, Act 633 (2003) on procurement systems

According to Best and Kaln (1998), the case study probes deeply and analyzes interactions between factors that explain present status or influence change or growth. Thus, data can be gathered in this regard through interviews or by observations by the researcher. Feldman (1996), states that in contrast to survey in which many people are studied, a case study is an in-depth study, intensive investigation of individual or small groups of people.

Babbie (1998) has identified three difficulties involved in using the descriptive approach for research as stated below;

i. The difficulty in ensuring that items on the questionnaire or interview guide are very clear.

ii. The difficulty of getting respondent to respond to the items in the right manner

iii. The difficulty in getting the questionnaires completed in time.

Despite these problems, the design has the potential of providing an authentic information on phenomenon under study. It would help in bringing out the actual problems and issues in delegation of authority. This design therefore best suits the study.

As a qualitative research, purposive sampling was used. A sample size of hundred (100) was derived, using the Public Sector Institutions in Ghana to design sample frame, while semistructured data collection technique was adopted for empirical examination.

The result in the response rate was 100\%. This was in according to studies by Mitchell (1989) and Evans (1991) which argues that a survey response rate should be calculated as the number of returned questionnaires divided by the total sample size and deduce to be greater than $80 \%$ (>80\%) from a small, random sample is considered preferable to a low response rate from a large sample. Further studies by Keeter et al. (2006) which compared results of a 5-day survey employing the Pew Research Center's usual methodology (with a 25\% response rate) with 
results from a more rigorous survey conducted over a much longer field period and achieving a higher response rate of $50 \%$. In 77 out of 84 comparisons, the two surveys yielded results that were statistically indistinguishable. In view of this, respondents for the study were drawn from various Public Institutional departments in charge of procurement. Table 1 depicts the number of respondents drawn from the various departments.

Table 1. Structure of respondent

\begin{tabular}{|l|l|l|}
\hline \multicolumn{1}{|c|}{$\begin{array}{c}\text { Some Listed Public Institution / Procurement Department } \\
\text { including it sub-department }\end{array}$} & Frequency & Percentage \\
\hline Ghana Cocoa Board & 9 & $9 \%$ \\
\hline Ghana Electricity Company & 20 & $20 \%$ \\
\hline Effia-Nkwanta Hospital & 5 & $5 \%$ \\
\hline Takoradi(European) Hospital & 2 & $2 \%$ \\
\hline Ghana Civil Aviation Authority & 3 & $3 \%$ \\
\hline Ghana Free Zone Board & 3 & $3 \%$ \\
\hline Investment Promotion Centre & 4 & $4 \%$ \\
\hline Library Authority & 5 & $5 \%$ \\
\hline National Fire Service & 12 & $12 \%$ \\
\hline Ghana Tourism Authority & 10 & $10 \%$ \\
\hline National Vocational Training Institute & 6 & $6 \%$ \\
\hline Komfo Anokye Teaching Hospital & 5 & $5 \%$ \\
\hline Ghana Water Company & 10 & $10 \%$ \\
\hline Ghana Prison Service & 6 & $6 \%$ \\
\hline TOTAL & & \\
\hline Source: & 100 & $100 \%$ \\
\hline
\end{tabular}

Source: Field Work, 2016

Table 2. Demographical Measurement of Respondent

\begin{tabular}{|c|c|c|c|}
\hline VARIABLE & $\begin{array}{l}\text { CATEGORY/ } \\
\text { demographic }\end{array}$ & FREQUENCY & PERCENTAGE \\
\hline \multirow[t]{2}{*}{ Gender } & Male & 91 & $91 \%$ \\
\hline & Female & 9 & $9 \%$ \\
\hline \multirow[t]{3}{*}{ Age } & $21-30$ & 12 & $12 \%$ \\
\hline & $31-45$ & 75 & $75 \%$ \\
\hline & $46-60$ & 10 & $10 \%$ \\
\hline
\end{tabular}




\begin{tabular}{|l|l|l|l|}
\hline $\begin{array}{l}\text { Working } \\
\text { Experience }\end{array}$ & 25 & $25 \%$ \\
\hline & $>5$ years & 61 & $61 \%$ \\
\hline & $>10$ years & 14 & $14 \%$ \\
\hline
\end{tabular}

Source: Field Work, 2016

\section{Research Question (QR) 1: Conformity of procurement activities by the listed Public Institutions with the Procurement Act, Act 663?}

Research question one, was asked to seek information from the respondents about their view on the procurement practices within the listed Public Institutions outlined in Table "1" above and whether they adhere to the procurement act. Table "3" below showed that procurement practices within the listed public Institutions conformed to the requirement of the procurement act. All the respondents affirmed the existence of a procurement committee as well as entity and evaluation committees. This was in accordance with article 14, 17 and 19 of the procurement act. However, it must be emphasized that this strict conformity with the procurement act was as a result of the periodic assessment by Public Procurement Authority. Majority of the respondents (83.0\%) $(\mathrm{n}=$ 83) responded in the affirmative that periodic assessment by PPA influences procurement practices in the listed Public Institutions. However, $17 \%$ of the respondents disagreed with that assertion. When asked their reasons for dissenting, the respondents stated the inability of Public Procurement Authority to sanction defaulting institution. They asserted that the PPA hardly sanction defaulting institution and therefore cannot be the reason why the institutions comply with the procurement act.

Table 3. Compliance with procurement Acts evidenced empirically

\begin{tabular}{|c|c|c|c|}
\hline VARIABLE & $\begin{array}{l}\text { CATEGORY/ } \\
\text { Activies }\end{array}$ & FREQUENCY & PERCENTAGE \\
\hline Establishment of Procurement Committee & Yes & 100 & $100 \%$ \\
\hline & No & - & 0.0 \\
\hline
\end{tabular}


Periodic Assessment by PPA Influence
procurement

The Extent of Enforcement with Procurement Act

Stakeholders Knowledge of Procurement Practice Practice
Yes

No
83

17

Strictly

Enforced

Partially

Enforced

Satisfactory

31

22

47
$31 \%$

Excellent

12

35

Good

Satisfactory

Poor

21

32
$83 \%$

$17 \%$

Source: Field Work, 2016

Though the public procurement act has established guidelines, principles and tender committees to take charge of its object clause in various public Institutions, however, it has failed to clearly provide for emergency procurement procedures. This has culminated in procurement officers resorting to their own discretion during emergency procurement which is subject to immense human error. The study therefore sought to ascertain from respondents the extent of adherence with the procurement act even under emergency situations. From Table 3, majority of the respondents $(31 \%)(\mathrm{n}=31)$ indicated that there is strict enforcement of the procurement act even under emergency situations whiles $47 \%$ indicated that enforcement of the procurement act under emergency situations is satisfactory since the act itself was not clear on it. This was in accordance to the 2006 report of the Public Procurement Authority, which indicated that the lack of clear procedures for emergency procurement remains one of the major ports of heckling, abuse, foul play and transgression in the business of public procurement right from the Board to subcommittee levels (Public Procurement Authority, 2006).

In assessing the level of compliance with the procurement law, stakeholder's knowledge of the procurement act has being identified as a major criterion for compliances. The result from table 3revealed that $35 \%$ of the stakeholder had good knowledge of procurement practices, while $12 \%$ of the stakeholder had excellent knowledge of procurement practices. This clearly confirm with 
Ohene- Addae (2012) studies which indicated a positive mean score of 0.30 when it comes to stakeholders' knowledge of procurement procedures.

Respondents were also asked to mention some factors in the opinion led to noncompliance with the procurement act. Their responses are indicated in table 4 below.

Table 4. Factors resulting to low compliance with the procurement Act

Response Data

Frequency

Percentage

Lack of Experienced Staff

Lack of support and co-operation from top management

52

$52 \%$

Lack of Training/ Mentoring by PPA

29

$29 \%$

Lack of Monitoring by PPA

15

$15 \%$

Source: Field Work, 2016

As indicated in Table 4 above, 52\% indicated that lack of experienced staff was responsible for the low compliance with the procurement act, $29 \%$ of the responses attributed the low compliance to the lack of support and co-operation from top management, whiles $15 \%$ stated the lack of education or training as the major cause of noncompliance. This was in accordance with the 2006 annual reports of the Public Procurement Authority which identified the lack of qualified procurement personnel, incorrect interpretation and application of some provisions of the procurement Act, slow pace in regularizing the Draft Regulations, lack of clear procedures for Emergency Procurement, lack of Training Avenues or Institutions, poor Record Management (haphazard keeping of files), poor handling of Supplierse Complaints, poor Procurement Planning, Mobilization \& Implementation, poor Contract Management and high cost of Advertisement (PPA, 2007) as the weakness in the public institutions that needed urgent attention. 
RQ. 2 Do procurement activities minimize corruptions, fraud and irregularities as Intended by the Procurement Act, Act 663 (2003?)

Table 5. Empirical evidence of effectiveness of procurement Act to curb corruption, fraud and irregularities

\begin{tabular}{|l|l|l|l|}
\hline Variable & Category/activities & Frequency & Percentage \\
\hline $\begin{array}{l}\text { Procurement Process used by Public } \\
\text { Institutions in Ghana }\end{array}$ & $\begin{array}{l}\text { National Competitive } \\
\text { Bid }\end{array}$ & 41 & $41 \%$ \\
\hline & $\begin{array}{l}\text { Request for quotation } \\
\text { Single Sourcing }\end{array}$ & 36 & $36 \%$ \\
\hline & Shopping & 5 & $18 \%$ \\
\hline & Yes & $5 \%$ \\
\hline Goods procured are delivered on time & No & 69 & $69 \%$ \\
\hline & Not Always & 21 & $21 \%$ \\
\hline $\begin{array}{l}\text { Impact of Procurement act in } \\
\text { minimizing corruption }\end{array}$ & Excellent & 10 & $10 \%$ \\
\hline & Goods & 23 & $23 \%$ \\
\hline & Satisfaction & 56 & $56 \%$ \\
\hline Goods procured are value for money & Yes & 21 & $21 \%$ \\
\hline & No & 57 & $57 \%$ \\
\hline & Not Always & 36 & $36 \%$ \\
\hline
\end{tabular}

Source: Field Work, 2016

The impact of effective procurement regime to minimize corruption had being identified by many research studies. Studies conducted by Adjei (2006), estimates that public procurement accounts for 50 to 70 per cent of the total government expenditure. Table 5 therefore, sought to seek respondents' view of whether the procurement act has help minimize corruption in the procurement process. As indicated in Table 5 above, $41 \%$ of the responses indicated procurement contracts are awarded through National Competitive Bid, 36\% through Request for quotation whiles $18 \%$ of responses indicated single sourcing as a mode of awarding contracts. 
Data in table 5 seek to justify that procured goods are delivered on time, because majority (69\%) of the respondents sampled agreed with the assertion that goods procured are delivered on time whiles $21 \%$ of the respondents disagreed.

Table 5 also depicts whether goods procured were in the opinion of the respondents value for money. The data empirically reveal that, $57 \%$ were of the view that goods procured were value for money, $36 \%$ were of the view that goods procured were not value for money whiles $7 \%$ of the respondents indicated that it was not always the case, that goods procured were value for money. This is in accordance with studies by Manu (2005) which indicated that an efficient and effective procurement process requires a comparative analysis of all relevant costs and benefits of each proposal throughout the whole procurement cycle, and that value for money is enhanced in public procurement by: encouraging competition, ensuring non-discrimination in procurement and using competitive procurement processes; promoting the use of resources in an efficient, effective and ethical manner; and making decisions in an accountable and transparent manner. This was however in contradiction with studies by the World Bank (2003) which identified substantial inefficiency in public procurement and concluded that the principle of "value for money" is not being achieved. However, it must be acknowledged that, there are some circumstances especially under emergency situations where the data elucidate that some of the public Institutions opted for single sourcing as indicated in table 5. According to Van Weele (2010) the downside of single sourcing is the increased dependence of the buyer on supplier and that it is very difficult to balance the pros and cons of single sourcing. Being dependent on a supplier can impose a number of risks, for example, constant price increases, lowering level of quality or delivery, slowed down or continuous improvement programmes (Leenders et al., 2002) and therefore must be avoided as much as possible.

Table 5 also shows that the procurement act (Act 663) has help minimize corruption in the procurement process, furthermore helped promote value for money. The finding that emerges from the respondents views on the impact of the procurement act in minimizing corruption. $23 \%$ of the respondents indicated that the impact of procurement act in minimizing corruption is excellent, $56 \%$ of the total sample size indicated that the impact of procurement act in minimizing corruption is good whiles $21 \%$ indicated that the impact of procurement act in 
minimizing corruption was satisfactory. This was in agreement with studies by Poisson (2010) which indicated that public officials are always confronted with corrupt practices and the volume of this corruption is within public procurement. Studies by Tanzi and Davoodi (1998) and Mauro (1997) have established a link between corruption, collusion and public procurement. They were of the view that corruption affects the allocation of public spending as investment decisions are influenced by the opportunity to obtain bribes. However, in most of these countries systems are being put in place to check corrupt officials. There is no doubt therefore that the effective and efficient implementation of the procurement act (Act 663) is the surest means to minimize or eradicate corruption in the public procurement process.

\section{QR 3: Has the procurement act help achieve transparency and accountability?}

Question three of the questionnaire tried to seek information from the respondents about their view on the procurement act on how the procurement act has help improve transparency and accountability in the procurement process in Public Institutions in Ghana. Their responses are indicated in table 6 below. The results revealed that the procurement act (Act 663, 2003) has helped improve transparency and accountability in the procurement process in various public Institutions by more than 50 percent. From the table, it is realized that $12 \%$ respondents sampled, indicated that the procurement act (Act 663, 2003) has help achieve accountability in an excellent manner while $39 \%$ believed that, the accountability level is good under the Acts. However $31 \%$ think it standard currently is only offering a better state in procurement actions while $18 \%$ thinks it performance is marginal and just ok to tolerate but not that encouraging. The state of transparency in the Acts 663, 2003 in procurement business was also inquired and 15\% responded, it excellent in it performance of presenting transparency, while $41 \%$ supported the argument of presenting transparency in their perspective to be good for Ghana. 33\% in their view accepted that, the level of transparency in the procurement operations is better to recommend with the exception of $11 \%$ that view it transparency under the Acts to be marginal.

This support the studies by Transparency International (2015) which indicated that global principles and minimum standards of transparency, integrity and accountability must be place to 
ensure public procurement is corruption free and that procurement laws must identify principles, standards and key steps needed to ensure a clean contracting process and procedures.

Table 6. The Procurement Act impact on transparency and accountability

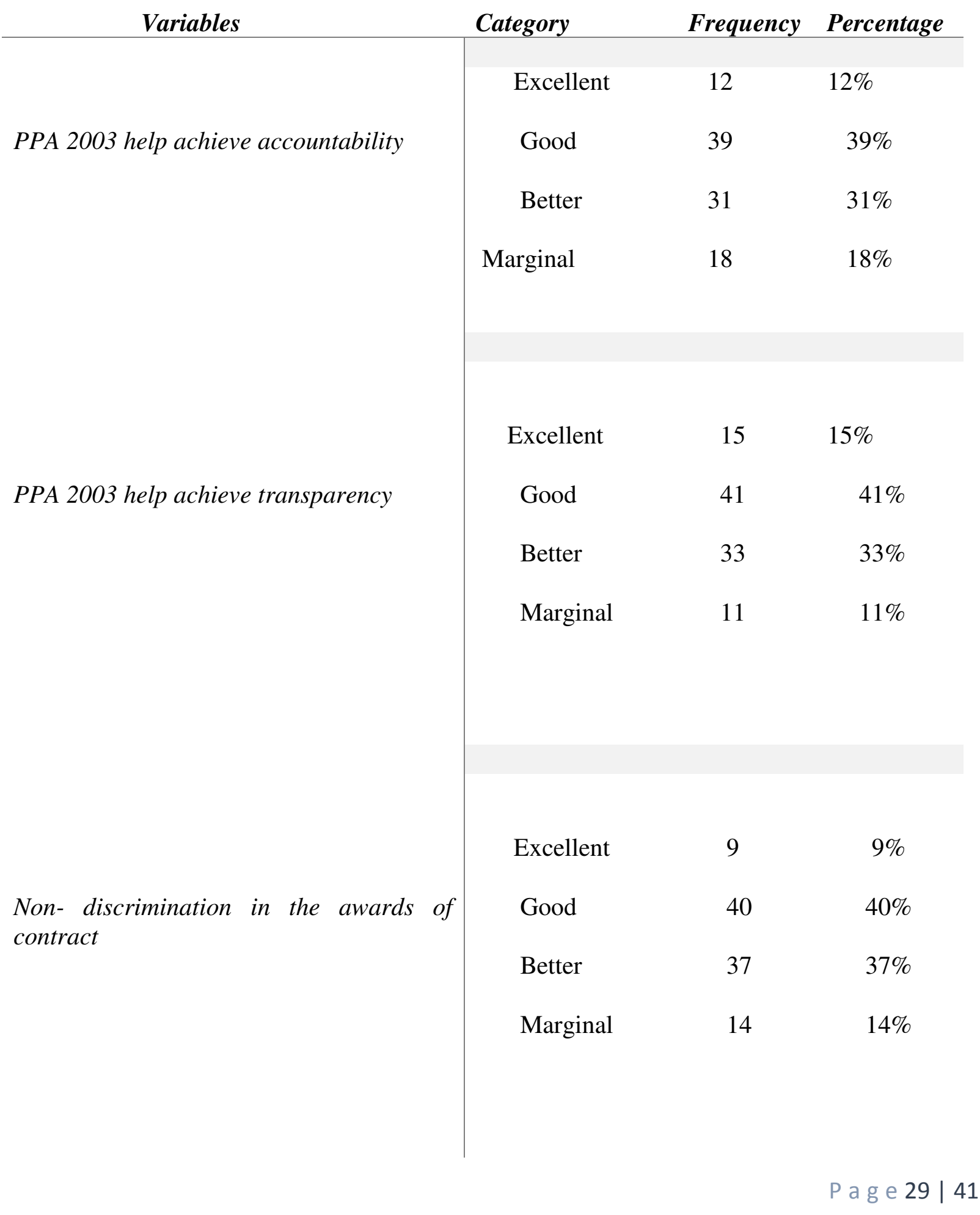


Source: Field Work, 2016

Data in the table 6 empirically indicate the variation of how people perceived discrimination in the award of contracts. 9\% respondents sampled indicated that the procurement act (Act 663, 2003) has help minimize discrimination in the awards of contract excellently, $40 \%$ respondents sampled indicated that the procurement act (Act 663, 2003) performance level in minimizing discrimination in the awards of contract is good to be celebrated while $37 \%$ respondents sampled indicated that the procurement act (Act 663, 2003) performance is better and believe there is more room for improvement. Unfortunately $14 \%$ respondents sampled indicated that the procurement act (Act 663, 2003) implementation assessment is marginal and believe it a disappointment and discredits to Ghana. However, this is in contradiction to studies by Søreide (2002) which concluded that corruption in public procurement makes the officials or the politicians in charge purchase goods or services from the best briber, instead of choosing the best price-quality combination. He further reiterated that the result may be construction projects several times as costly as necessary, or the acquisition of goods not actually needed. However, it is difficult to determine a public official's involvement corruption practices since it is a two ways street where both parties (the giver and taker) benefits. The researcher therefore believes that with the enactment of the procurement act which states how public official should behave when procuring good and services corruption and collusion have being greatly minimized. There by helped improved accountability and transparency within the public procurement system.

\section{QR 4. What could be done to improve procurement practice in Public Institutions?}

The question sought to find out from the respondents their views on way to improve on the procurement practices at the Public Institutions. The answer to this question was displayed in Table 7. From the result, the outcome revealed that there is the need for improvement or amendments to the procurement law in order to reflect circumstance on the ground especially within emergency situations. Table 7 showed that there is the need for the revision on thresholds as $17 \%$ responded in that favour. Table 7 again revealed training (capacity building) is a sure 
way of improving compliance as most staff in charge of procurement operations within public institutions lack staff with professional competence and experience as $41 \%$ responded to attest to that fact empirically. This meant that if staffs are adequately vest in the procurement law, then compliance would increase as sometimes staffs do not comply with the provisions of the law because they are simple unaware of these provisions. Data in the table "7" also indicated that the PPA only gives recommendations and directives to defaulting institutions and therefore the need for the PPA to sanction defaulting institutions for non-compliance as below data project $35 \%$ in favour of such action under the procurement Acts.

Table 7: Recommendations for Improvement

\begin{tabular}{|c|c|c|}
\hline Response & Frequency & Percentage \\
\hline Revision of Threshold & 17 & $17 \%$ \\
\hline Training ( Capacity Building) & 41 & $41 \%$ \\
\hline Application of sanction for non-compliance & 35 & $35 \%$ \\
\hline Frequent monitoring by PPA & 7 & $7 \%$ \\
\hline
\end{tabular}

Source: Field Work, 2016

Throughout the study and review of literature one comes to a conclusion that public procurement is one of a number of activities within the operations of public entities that requires special attention in promoting good corporate governance and better overall value for money. The study revealed that to improve the efficiency of the procurement act there is the need for capacity building and frequent monitoring by the Public Procurement Authority. This was in accordance with studies by Knudsen (1999) that suggested that procurement performance starts from purchasing efficiency and effectiveness in the procurement function in order to change from being reactive to being proactive to attain set performance levels in an entity. 
The mission of public procurement is to ensure and enable public institution meet their policy and business objectives in the delivery of better effective and efficient public services. The study revealed that there is the need to for the periodic revision of thresholds to meet current market trends. This would go a long way to improve on organizational performance. According to Van Weele (2006) purchasing performance is considered to be the result of two elements: purchasing effectiveness and purchasing efficiency. Performance provides the basis for an organization to assess how well it is progressing towards its predetermined objectives, identifies areas of strengths and weaknesses and decides on future initiatives with the goal of how to initiate performance improvements. This means that purchasing performance is not an end in itself but a means to effective, efficient control and monitoring of the purchasing function.

\subsection{RECOMMENDATION AND CONCLUSION}

\section{Main Findings}

1. Most of the Public Institutions in Ghana has more male employees than female involved in procurement process.

2. Procurement practices within this Public Institutions conform to the procurement act (Act $663,2003)$.

3. Majority of the respondents indicated that there is strict enforcement of the procurement act even under emergency situations.

4. Stakeholders have a fair knowledge of procurement practices within the Public Institutions

5. The lack of experienced staff is a major factor responsible for the low compliance with the procurement act.

6. Majority of the procurement contracts within by the Public Institutions are awarded through National Competitive Bid. 
7. Most of the Public Institutions sometimes opt for single sourcing especially under emergency situations. This eventually creates room for corrupt practices to occur. In this context, the procurement law does not minimize fraud and other forms of irregularities in procurement in Public Institutions. The procurement needs of the various public Institutions must therefore be well planned to take into consideration possible emergency situations in order to strengthen the procurement processes.

8. The procurement act has help minimize corruption in the procurement process at the Public Institutions

9. The procurement act has help improve transparency and accountability in the procurement process in Public Institutions.

10. There is the need for improvement or amendments to the procurement law in other to reflect circumstance on the ground, especially with emergency situations.

\section{Conclusion}

The study revealed that the current procurement system in use at various Public Institutions in Ghana (i.e. the system prescribed by Act 663) is better than the one used prior to the enactment of Act 663. The procurement Act (Act 663) has impacted positively on public procurement practice in the area of transparency, accountability and non-discrimination. However, the procurement law is still silent on a clear cut procedure to adopt, especially during emergency situations, the reason behind why most Public Institution therefore opt for single sourcing especially under emergency situations. This has the tendency of introducing some levels of malpractices, frauds, irregularities and corruption within the system. The study also revealed that there is some top level management interference within the procurement process that does not facilitate compliance in most of the Public Institution administrational system. This requires the central government "will" and capacity to control them. 


\section{Recommendations}

Even though compliance with the procurement act among Public Institutions was generally high, there is still room for improvement. From the study, the following recommendations were made.

1. Top level management in Public Institutions should stop interfering in procurement process since such behaviors do not give value for money.

2. Advertisement should be intensified so as to allow more contractors or supplier to bid for contracts not only registered contractors as this would enable the various public Institutions to maximize a higher benefit from competition.

3. There is the need for the separation of Procurement Committee, Tender Entity Committee and Tender Evaluation Committee, so that they can serve as checks on each other.

4. The PPA, 2003 (ACT 663) should be amended to include provisions for electronic procurement and sustainable procurement issues. This will improve transparency, accountability, and compliance respectively as well as ensure sustainable best practice in our public procurement system.

5. The threshold contained in schedule three of the PPA 2003 (ACT663) must be increased to be in tune with prevailing market trends. This will allow more flexibility in decision making and permit procurement entities to procure more swiftly.

6. The Public Procurement Authority must offer serious punishment to institution and individual who fails to comply with procurement act (ACT 663, 2003). Such as the infringement procedure practiced by the EU under the EU public procurement laws in which offenders of the law are actively prosecuted to serve as a deterrent. 


\subsection{REFERENCE}

1. Adjei, A.B. (2006). Message from the Chief Executive ${ }^{e e}$ Public Procurement Board, June 2006. Retrieved from www.ppbghana.org/story on 22nd March, 2015.

2. Agyekum-Kwatiah, F. (2014).Impact Of Public Procurement Act, 2003 (Act 663) On Public Procurment Practice In Korle Bu Teaching Hospital. Thesis Submitted To The Department Of Building Technology, Kwame Nkrumah University Of Science And Technology.

3. Alarcón, L.F., Rivas, R., \& Serpell, A. (1999). Evaluation And Improvement Of The Procurement Process In Construction Projects. Proceedings IGLC-7. 7th Conference of the International Group for Lean Construction, IGLC-7. Berkeley, 26 - 28 July 1999. Ed. by Iris D. Tommelein. University of California (1999).

4. Amedahe, F. K. (2002). Fundamentals of Educational Research. Mimeograph, UCC. Cape Coast.

5. Ameyaw, C., Mensah, S., \& Osei-Tutu, E. (2012). Public procurement in Ghana: The implementation challenges to the Public Procurement Law 2003 (Act 663). International Journal of Construction Supply Chain Management, 2(2): 55-65.

6. Ameyaw, C., Mensah, S. and Osei-Tutu, E. (2011). Challenges facing the smooth implementation of Act 663, 2003 of Ghana. West African Built Environment Research (WABER) Conference, University of Reading, 2011.

7. Arrowsmith, S. (2010) Public procurement: Basic concepts and the coverage of procurement rules, in Public procurement relations: an introduction. EU Asia Inter University Network. 
8. Babbie, E. R. (1992). The practice of social research. Belmont, CA: Wadsworth Publishing.

9. Basu, C. (1995). Importance of Strategic Sourcing Skills. Retrieved from http://smallbusiness.chron.com/importance-strategic-sourcing-skills-38123 .html. on 23rd April, 201

10. Best, J.W., \& Kaln, J.V. (1998). Research in education. Boston: Allyn and Bacon.

11. Charted Institute of Procurement and Supply [CIPS] (2013). The Definitions of Procurement and Supply Chain Management. Retrieved from https://www.cips.org/Documents/Knowledge/Procurement-Topics-and-Ski 1ls/13-SRMand-SC-Management/Supplier-Relationship-Management/def initionsofprocurementandscm.pdf. 20th March, 2015.

12. Cole A. (2007). Procurement Definition, EzineArticles.com/?expert=Alison_Cole

13. Dabaga, J. (2014). Retrieved from http://opinion.myjoyonline.com /pages/feature/201309/112500.php on 30 ${ }^{\text {th }}$ March, 2015.

14. European Union [EU] (2014). How the EU works. Retrieved from http://europa.eu/abouteu/index_en.htm on $31^{\text {st }}$ March, 2014.

15. Evans, S.J. (1991). Good surveys guide. British Medical Journal, 302(6772):302-3.

16. Fink, A., \& Kosecoff, J. (1998). How to conduct surveys: A step-by-step guide.Beverly Hills, CA: Sage Publication, Inc.

17. Fowler, F. (2002). Survey Research Method (3rd edition).Thousand Oaks: SAGE Publications, Inc. 
18. Gay, L.R. (1992). Educational Research: Competencies for analysis and application (4th Ed.). New York: Macmillan Publishing Company.

19. Gnanih, E. L. (2012). Investigating The Effect Of The Public Procurement Law On The Ghanaian Educational Sector. Thesis Submitted to the Department Of Business Administration Ashesi University College Ghanaweb (2007). Efficient, transparent procurement is the key Baa-wiredu. Retreievedfromhttp://www.ghanaweb.com/GhanaHomePage/NewsArc hive/artikel.php?ID=129351 on $30^{\text {th }}$ March, 2015.

20. Handfield, R. (2011). The Procurement Process - Implementing the Plan: Procurement: A Tutorial. Retrieved from http://scm.ncsu.edu/scm-articles/article/the-procurementprocess-implementing-the-plan-procurement-a-tutorial on 24th March, 2014.

21. Himmie, E. L. (2010). The Benefits of Effective Procurement Planning. Retrieved from http://goxi.org/profile/HimmieEugeneLangford.html on 23rd April, 2014.

22. International Association for Contract and Commercial Management [IACCM] (2011).Contract and Commercial Management-The Operational Guide. London: Van Haren Publishing.

23. Keeter, S., Courtney, K., Dimock, M., Best, J., \& Craighill, P. (2006). Gauging the Impact of Growing Nonresponse on Estimates from a National RDD Telephone Survey. Public Opinion Quarterly, 70(5): 759-779.

24. Kumak, E. (2012). Understanding Public Procurement - A Library Review. Retrieved from: www.devtplanconsult.org on $30^{\text {th }}$ March, 2015.

25. Lavrankas, P.J. (2008). Encyclopedia of Survey Research Methods.Thousand Oaks: SAGE Publications, Inc. 
26. Lynch, J. (2014). Steps in the Public Procurement Process. Retrieved from http://www.procurementclassroom.com/steps-in-the-public-procurement-process/ on $20^{\text {th }}$ April, 2014.

27. Lynch, J. (2014). Procurement Planning and the Procurement Plan: Why are they Important? Retrieved from http://www.procurementclassroom.com/ procurementplanning-and-the-procurement-plan-why-are-they-important/ on $23^{\text {rd }}$ April 2014.

28. Matthew, H. (2010). EU Public Procurement Rules. The International Comparative Legal Guide To: Public Procurement 2010. Retrieved from http://www.iclg.co.uk/khadmin/Publications/pdf/3381.pdf on 11th April. 2015.

29. Mauro, P. (1997), "The Effects of Corruption on Growth, Investment, and Government Expenditure: A Cross-Country Analysis". Corruption and the Global Economy, (Washington D.C.: Institute for International Economics), 83-107.

30. Miles, J. (2015). Defining Procurement: Could Procurement Be The Most Important Aspect Of Your Business? Retrieved from http://www.valuestreamguru.com/?p=195 on $14^{\text {th }}$ April, 2015

31. Mitchell, R.C. (1989). Using surveys to Value Public Goods: The Contingent Valuation Method. Washington, DC: Resources for the Future.

32. Moore, D. S., \& McCabe, P. G. (2006). Introduction to the Practice of Statistics (5th $E d$.). London: W.H. Freeman \& Company.

33. Ohene-Addae, A. A. (2012). An Assessment of the Impact of Efficient Procurement Practices on the Corporate Performance of a Public University: A Case Study of Kwame Nkrumah University of Science and Technology (KNUST). Thesis submitted to the 
Kwame Nkrumah University Of Science And Technology Institute Of Distance Learning (Idl).

34. Okine, C. B. (2014). No single source procurement - Entities warned. Retrieved from http://www.graphic.com.gh/business/business-news/16503-no-single-sourceprocurement-entities-warned.html on 28th April, 2015.

35. Public Procurement Oversight Group (2002). Public Procurement Act, 2003 (Act 663). Ghana Publishing Company (Assembly Press): Ghana.

36. Public Procurement Board (2007). Procurement Planning Short term training manual on the Public Procurement Act (Act 663), Module 9, September 2007.

37. Public Procurement Board (2007). Procurement Principles And Ethics ${ }^{\mathrm{e}}$, Short term training manual on the Public Procurement Act (Act 663), Module 3, September 2007.

38. Rose-Ackerman, S. (1999), Corruption and Government. Causes, Consequences and Reform (Cambridge: Cambridge University Press).

39. Sarantakos, S. (1997). Social research (2nd ed.). New York: Palgrave Publishers Ltd.

40. Sivek, S (2010). Importance of Sampling in Statistical Analysis. Retrieved from http://www.ehow.com/about_5106424_importance-sampling-statistical- analysis.html on March, 7, 2015.

41. Smith, S. (2010). What Is the Meaning of Sample Size? Retrieved from http://www.ehow.com/facts_5988804_meaning-sample-size_html on 7th March, 2015.

42. Soreide, T. (2002). Corruption in public procurement. Causes, consequences and cures. Bergen: Chr. Michelsen Institute (CMI Report R 2002:1). 
43. Suleiman, Y. (2010). Overview of public procurement reforms in Commonwealth Africa: strategy, successes and challenges. A paper presented at Public Procurement Forum at St. Lucia, the Caribbean.

44. Tanzi, V. and H. Davoodi (1998), "Corruption, Public Investment, and Growth", International Monetary Fund Working Paper, 97/139.

45. The World Bank (2013). Ghana's Comprehensive Approach to Public Procurement Reform. Retrieved from http://www.worldbank.org /en/news/feature /2013/02/04/Ghana8217-s-Comprehensive-Approach-to-Public-Procurement-Reform on 30 ${ }^{\text {th }}$ March, 2015.

46. Transparency International (2015). Curbing corruption in public procurement. Retrieved fromhttp://www.transparency.org/whatwedo/activity/curbingcorruptioninpublicprocurem ent.html on $31^{\text {st }}$ July, 2015.

47. Wallace, W. L., \& Xia, Y. L. (2014). Delivering Customer Value through Procurement and Strategic Sourcing: A Professional Guide to Creating a Sustainable Supply Network. New York: Pearson FT Press.

48. World Bank. (2003). Ghana 2003 Country Procurement Assessment Report. Washington, DC: Ghana Country Department. 


\subsection{APPENDIX}

\section{Definition of Terms}

- Procurement - The act of obtaining goods, services or works from an external source.

- Procurement Act - a comprehensive legislation designed to eliminate the shortcomings and organizational weaknesses which were inherent in public procurement in Ghana

- Public Institution - an institution that is backed through public funds and controlled by the state.

- Public Procurement Authority - the institution responsible for the harmonization of the process of procurement in the public service to secure a judicious, economic, and efficient use of public funds to ensure that public procurement is carried out in a fair, transparent and non-discriminatory manner while promoting a competitive Local Industry.

- Procurement Thresholds: It is the type of goods or service and the Ghana cedi (Ghc.)value in this case, of determining the purchasing process to be used by an agency framed in a table listing 